\title{
Eco-friendly preparation of chitooligosaccharides with different degrees of deacetylation from shrimp shell waste and their effects on the germination of wheat seeds
}

\author{
Xiaodan $\mathrm{Fu}^{1} \cdot \operatorname{Lin} \mathrm{Zhu}^{1} \cdot \mathrm{Li} \mathrm{Li}^{1} \cdot \operatorname{Tan}_{\mathrm{Zhang}}{ }^{1} \cdot \mathrm{Meng} \mathrm{Li}^{1} \cdot \mathrm{Haijin} \mathrm{Mou}^{1}$
}

Received: 10 June 2019 / Accepted: 11 September 2019 / Published online: 6 November 2019

(c) The Author(s) 2019

\begin{abstract}
Production of chitosan and its derivatives by traditional methods involves the excessive use of a reaction solution comprised of sodium hydroxide and hydrochloric acid. Waste water resulting from this process has limited the application of chitosan as a fertilizer as the process causes serious environmental pollution. Specifically, the resulting waste water contains high levels of dissolved nitrogen and minerals from shrimp shells. In this study, an eco-friendly method was established to produce chitooligosaccharides (COS) with different degrees of deacetylation (DDAs) from shrimp shell waste. At a solid-tosolvent ratio of 1:6, the degree of demineralization was above $90 \%$ with the treatment of $30 \mathrm{~g} \cdot \mathrm{L}^{-1} \mathrm{H}_{3} \mathrm{PO}_{4}$, and the degree of deproteinization was above $80 \%$ when treated with $30 \mathrm{~g} \cdot \mathrm{L}^{-1} \mathrm{KOH}$ at $70{ }^{\circ} \mathrm{C}$. Chitosans with different DDAs were obtained by microwave-assisted $\mathrm{KOH}$ metathesis and the $\mathrm{COS}$ with $\mathrm{Mw}$ approximately $1500 \mathrm{Da}$ were then prepared by oxidative degradation. In summary, $33.73 \mathrm{~kg} \mathrm{H}_{3} \mathrm{PO}_{4}, 12.77 \mathrm{~kg}$, and $241.31 \mathrm{~kg} \mathrm{KOH}$ were supplied during the processes of demineralization, deproteinization, and deacetylation of $100 \mathrm{~kg}$ shrimp shell waste, respectively. The process water was totally recycled, demonstrating that the shrimp shell could be wholly transformed into fertilizer. The entire process created a product with the fractions of $\mathrm{N}: \mathrm{P}_{2} \mathrm{O}_{5}: \mathrm{K}_{2} \mathrm{O}: \mathrm{COS}=7.94: 24.44: 10.72: 18.27$. The test on the germination promotion of wheat seeds revealed that the COS with $72.12 \%$ DDA significantly promoted germination. This work demonstrated the use of an eco-friendly preparation method of COS with a specific degree of deacetylation that can be applied as a fertilizer.
\end{abstract}

Keywords Chitooligosaccharide $\cdot$ Deacetylation degree $\cdot$ Phosphoric acid $\cdot$ Potassium hydroxide $\cdot$ Germination promotion

\section{Introduction}

Shrimp shells are a natural resource with complex composition that includes chitin, protein, and astaxanthin. Chitooligosaccharides (COS), derivatives of chitin, are homooligomers or hetero-oligomers of $N$-acetyl-glucosamine and D-glucosamine linked by $\beta$-1,4-glycosidic bonds (Aam et al. 2010). The process of extracting and preparing COS from shrimp shells involves demineralization, deproteinization, deacetylation, and depolymerization. Traditional chemical

Edited by Xin Yu.

Xiaodan Fu and Lin Zhu contributed equally.

Haijin Mou

mousun@ouc.edu.cn

1 College of Food Science and Engineering, Ocean University of China, No. 5 Yushan Road, Qingdao 266003, China processes involved in the extraction of chitosan from shrimp shells mostly use hydrochloric acid $(\mathrm{HCl})$ for demineralization (Mohammed et al. 2013; Younes et al. 2016) and sodium hydroxide $(\mathrm{NaOH})$ for deproteinization and deacetylation (Benhabiles et al. 2012; Kumari et al. 2015). The chitosan is then oxidatively degraded to COS, a method that is highly economical as well as effective (Ma et al. 2014b). However, the excessive usage of $\mathrm{HCl}$ and $\mathrm{NaOH}$ results in serious problems, specifically environmental pollution from the liquid waste that is rich in protein and $\mathrm{NaCl}$, limiting the use of chitosan as a fertilizer.

COS have been widely used in agriculture, including the promotion of wheat seed germination (Hamel and Beaudoin 2010; Cristóbal et al. 2012). Generally, the germination percentage of wheat seeds is low due to fluctuations in environmental temperature and moisture, thus, influencing the production of wheat (Nyachiro et al. 2002a, b; Singkhornart et al. 2014). It has been reported that the germination percentage of wheat seeds could be improved if the seeds are 
pretreated by soaking in either chitosan or COS (Ma et al. 2014a; Tawaha et al. 2013). It has also been shown that the degree of deacetylation (DDA) of COS affects the physiology of plants, including growth promotion and stress resistance (Cabrera et al. 2006; Vander et al. 1998). However, limited attention has been given to clarifying the relationship between the DDA of COS and its germination promotion activity.

In this study, an eco-friendly method was established for the production of COS, using phosphoric acid $\left(\mathrm{H}_{3} \mathrm{PO}_{4}\right)$ for demineralization and potassium hydroxide $(\mathrm{KOH})$ for deproteinization and deacetylation. The effects of the COS with different DDA on the germination of wheat seeds were also studied. Lastly, enzyme activity involved in energy metabolism and biochemical composition of seeds during the early stages of germination were determined for further evaluation.

\section{Results and discussion}

\section{Extraction of chitin from shrimp shells}

In this study, $\mathrm{H}_{3} \mathrm{PO}_{4}$ and $\mathrm{KOH}$ were used to remove minerals and proteins, instead of the traditionally used $\mathrm{HCl}$ and $\mathrm{NaOH}$, respectively. The degree of demineralization (DDM) varied from $37.18 \%$ to $94.04 \%$ when the concentration of $\mathrm{H}_{3} \mathrm{PO}_{4}$ was increased from 10 to $30 \mathrm{~g} \cdot \mathrm{L}^{-1}$ (Table 1). Different solid-to-solvent ratios could influence the demineralization of shrimp shells. The DDM was over $90 \%$ when $30 \mathrm{~g} \cdot \mathrm{L}^{-1} \mathrm{H}_{3} \mathrm{PO}_{4}$ with a solid-to-solvent ratio of 1:6 was used for $30 \mathrm{~min}$. The degree of deproteinization (DDP) varied from $52.23 \%$ to $85.65 \%$ when increasing the concentration of $\mathrm{KOH}$ from 10 to $30 \mathrm{~g} \cdot \mathrm{L}^{-1}$ (Table 2), however, no significant increase was observed with a concentration above $30 \mathrm{~g} \cdot \mathrm{L}^{-1}$.
It is necessary to remove the minerals (demineralization) and proteins (deproteinization) during the extraction of chitin from shrimp shells (Younes et al. 2014). Many industries extensively use chemicals for demineralization and deproteinization during the extraction process. In general, $\mathrm{HCl}$ and $\mathrm{NaOH}$ have been efficiently used for demineralization and deproteinization (Al Sagheer et al. 2009; Percot et al. 2003). The DDM was $93.8 \%$ with the use of $0.25 \mathrm{~mol} \cdot \mathrm{L}^{-1} \mathrm{HCl}$ (John et al. 2006), and the DDP reached $80 \%$ with the use of $50 \mathrm{~g} \cdot \mathrm{L}^{-1} \mathrm{NaOH}$ at $90{ }^{\circ} \mathrm{C}$ for $1 \mathrm{~h}$ (Holanda and Netto 2006). However, the liquid waste generated during the process is harmful to the growth of plants due to remaining chlorine in the chitin, thus limiting the further application of chitin and its derivatives as fertilizers.

Compared with earlier studies using $\mathrm{HCl}$ and $\mathrm{NaOH}$, no discernable differences of DDM or DDP were observed for the treatment of $\mathrm{H}_{3} \mathrm{PO}_{4}$ and $\mathrm{KOH}$ in this study. Moreover, the liquid waste, generated during the demineralization and deproteinization using $\mathrm{H}_{3} \mathrm{PO}_{4}$ and $\mathrm{KOH}$, was rich in phosphorus, potassium, and nitrogen, which are the main constituents of fertilizers. Process water in this study was totally recycled, which provided an eco-friendly method for the preparation of chitosan and its derivatives.

\section{Production of chitosan and $\operatorname{COS}$}

Microwave-assisted chemical reactions are rapid and efficient. In this study, the DDA of chitosans was enhanced by increased microwave heating time. Chitosan with four different DDAs $(63.79 \%, 72.12 \%, 79.34 \%$, and $88.15 \%)$ were prepared by microwave heating with $450 \mathrm{~g} \cdot \mathrm{L}^{-1} \mathrm{KOH}$ for 6.0-8.5 min (Table 3). Compared with the traditional method using $\mathrm{NaOH}$, the combination presented was more efficient (Yen et al. 2009; Viarsagh et al. 2010). Microwave heating is an important processing step for preparation of
Table 1 Effects of phosphoric acid concentration and the solid-to-solvent ratio on demineralization of shrimp shells

\begin{tabular}{|c|c|c|c|c|c|c|}
\hline & \multicolumn{3}{|c|}{$\mathrm{H}_{3} \mathrm{PO}_{4}$ conc. $\left(\mathrm{g} \cdot \mathrm{L}^{-1}\right)$} & \multicolumn{3}{|c|}{ Solid/solvent ratio } \\
\hline & $\overline{10}$ & 30 & 50 & $1: 4$ & $1: 6$ & $1: 8$ \\
\hline DDM (\%) & $37.18 \pm 1.36^{\mathrm{a}}$ & $94.04 \pm 0.52^{b}$ & $94.28 \pm 0.36^{\mathrm{b}}$ & $68.61 \pm 0.19^{\mathrm{a}}$ & $94.51 \pm 0.53^{b}$ & $94.99 \pm 1.31^{b}$ \\
\hline
\end{tabular}

Different letters indicate statistically significant results $(P<0.05)$ based on one-way ANOVA with Tukey's test. DDM is the degree of demineralization. Data are expressed as means \pm SDs $(n=3)$

\begin{tabular}{llllllll}
\hline & \multicolumn{5}{l}{ KOH conc. $\left(\mathrm{g} \cdot \mathrm{L}^{-1}\right)$} & & \multicolumn{5}{l}{ Temperature $\left({ }^{\circ} \mathrm{C}\right)$} \\
\cline { 2 - 4 } \cline { 6 - 7 } & 10 & 30 & 50 & 50 & 70 & 90 \\
\hline $\operatorname{DDP}(\%)$ & $52.23 \pm 0.27^{\mathrm{a}}$ & $85.65 \pm 1.06^{\mathrm{b}}$ & $84.10 \pm 1.06^{\mathrm{b}}$ & & $75.61 \pm 0.56^{\mathrm{a}}$ & $84.58 \pm 0.21^{\mathrm{b}}$ & $83.87 \pm 0.79^{\mathrm{b}}$ \\
\hline
\end{tabular}

Different letters indicate statistically significant results $(P<0.05)$ based on one-way ANOVA with Tukey's test. DDP is the degree of deproteinization. Data are expressed as means \pm SDs $(n=3)$
Table 2 Effects of potassium hydroxide concentration and temperature on deproteinization of shrimp shells 
Table 3 The degree of deacetylation, viscosity [ $\eta]$, and molecular weight $\left(M_{\mathrm{v}}\right)$ of chitosans under different microwave heating times

\begin{tabular}{lllll}
\hline $\begin{array}{l}\text { Microwave heating time } \\
(\mathrm{min})\end{array}$ & 6 & 7 & 8 & 8.5 \\
\hline $\begin{array}{l}\text { Degree of deacetylation } \\
(\%)\end{array}$ & 63.79 & 72.12 & 79.34 & 88.15 \\
$\begin{array}{l}{[\eta]\left(\mathrm{mL} \cdot \mathrm{g}^{-1}\right)} \\
M_{\mathrm{v}}(\mathrm{Da})\end{array}$ & $/$ & 754 & 557 & 561 \\
\hline
\end{tabular}

chitosan with specified molecular weight distribution. The molecular weight $\left(17.4 \times 10^{5}-5.7 \times 10^{5} \mathrm{Da}\right)$ and viscosity of chitosans decreased with increased microwave heating time, indicating that the combination of microwave heating and alkali efficiently destroyed the carbohydrate chain (Bajaj et al. 2011).

According to the FTIR spectrum of chitin and chitosans (Fig. 1), the $\mathrm{C}=\mathrm{O}$ bands were approximately at around $1626.61 \mathrm{~cm}^{-1}$ and $1660.29 \mathrm{~cm}^{-1}$ and $\mathrm{N}-\mathrm{H}$ band was at $1557.99 \mathrm{~cm}^{-1}$. The characteristic absorption bands at $3445.62 \mathrm{~cm}^{-1}$ corresponded to $\mathrm{OH}$ stretching, while those at $3268.62 \mathrm{~cm}^{-1}$ and $3106.16 \mathrm{~cm}^{-1}$ corresponded to $\mathrm{NH}$ stretching. The absorption bands at $1417.07 \mathrm{~cm}^{-1}$ and $1378.51 \mathrm{~cm}^{-1}$ were attributed to $\mathrm{CH}_{2}$ and $\mathrm{CH}$ bending, respectively. Similar absorption bands were observed both with chitin (Fig. 1a) and chitosans with different DDA (Fig. 1b-e). Moreover, functional groups of chitosan, such as the $\mathrm{C}=\mathrm{O}$ and $\mathrm{N}-\mathrm{H}$ bands, were all presented (Fig. 1b-e).

Chitosans with different DDA $(63.79 \%, 72.12 \%, 79.34 \%$, and $88.15 \%$ ) were oxidatively degraded with $\mathrm{H}_{2} \mathrm{O}_{2}$ to produce COS. HPLC analysis revealed that the molecular weights of the COS were 1559, 1553, 1599, and $1526 \mathrm{Da}$, respectively.

According to the component analysis results, whiteleg shrimp shell was rich in protein $(49.61 \%)$, minerals (29.06\%), and chitin (21.33\%) (Table 4). In summary, $33.73 \mathrm{~kg} \mathrm{H}_{3} \mathrm{PO}_{4}, 12.77 \mathrm{~kg}$, and $241.31 \mathrm{~kg} \mathrm{KOH}$ were supplied during the processes of demineralization, deproteinization, and deacetylation for $100 \mathrm{~kg}$ shrimp shell waste, respectively. The whole process created a product with the fractions of $\mathrm{N}: \mathrm{P}_{2} \mathrm{O}_{5}: \mathrm{K}_{2} \mathrm{O}: \mathrm{COS}=7.94: 24.44: 10.72: 18.27$. The supply of $\mathrm{N}, \mathrm{P}$, and $\mathrm{K}$ can also be adjusted according

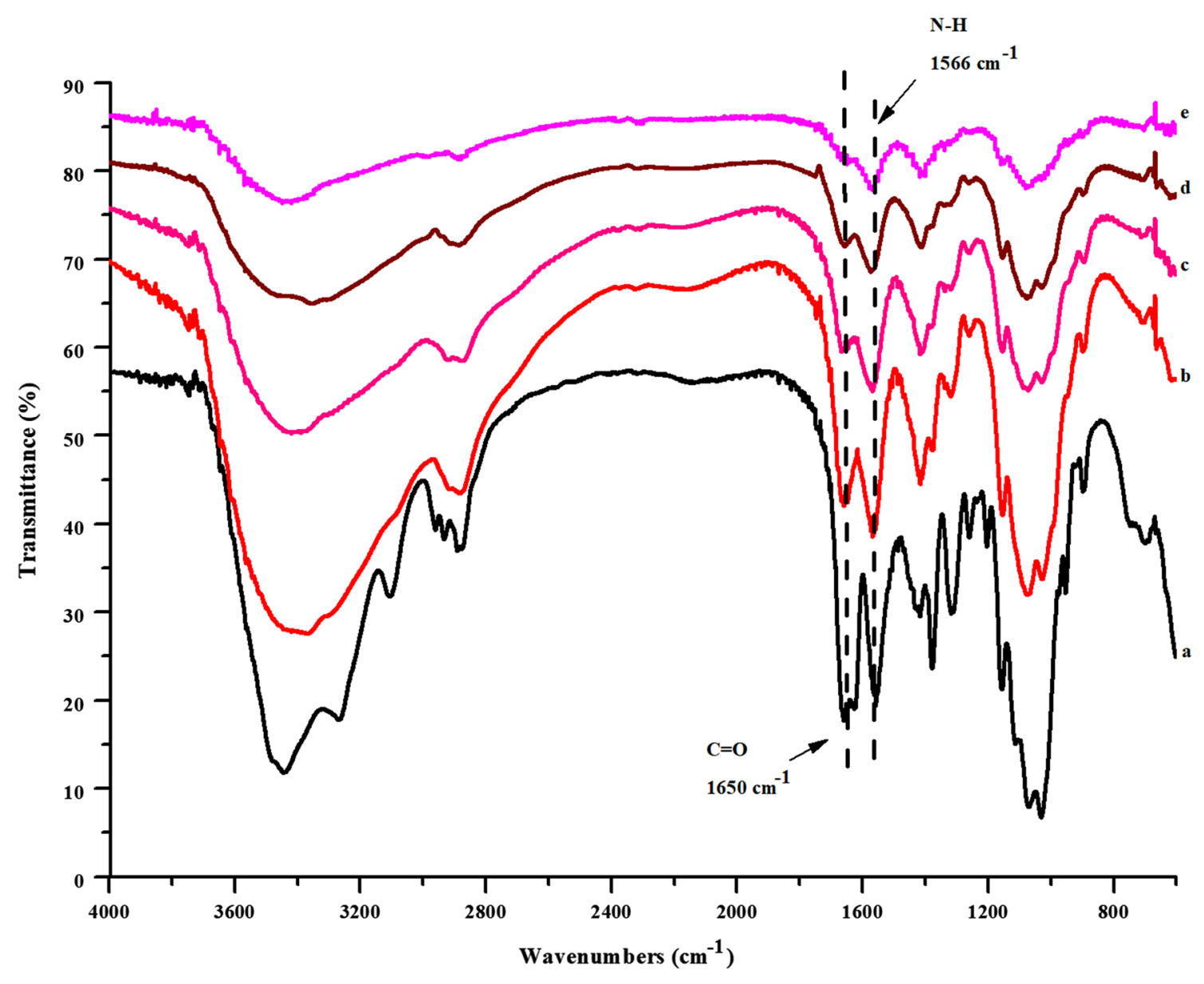

Fig. 1 FTIR spectra of chitin and chitosan with different degrees of deacetylation. a: Chitin; b-e: chitosans with different degrees of deacetylation $(63.79 \%, 72.12 \%, 79.34 \%$, and $88.15 \%)$ 
Table 4 The evaluation of input and output in process

\begin{tabular}{ll}
\hline Components & Mass $(\mathrm{kg})$ \\
\hline Components of shrimp shell & \\
Shrimp shell & 100 \\
Protein & 49.61 \\
Mineral & 29.06 \\
Chitin & 21.33 \\
Input of raw materials & \\
$\mathrm{H}_{3} \mathrm{PO}_{4}$ (demineralization) & 33.73 \\
$\mathrm{KOH}_{\text {(deproteinization) }}$ & 12.77 \\
$\mathrm{KOH}$ (deacetylation) & 241.31 \\
$\mathrm{HAc}$ (dissolved chitosan) & 37.54 \\
Water & 2355.96 \\
$\mathrm{Components} \mathrm{of} \mathrm{products}$ & \\
$\mathrm{Chitooligosaccharide}$ & 18.27 \\
$\mathrm{~N}$ & 7.94 \\
$\mathrm{P}_{2} \mathrm{O}_{5}$ & 24.44 \\
$\mathrm{~K}_{2} \mathrm{O}$ & 10.72 \\
Waste & 0 \\
\hline
\end{tabular}

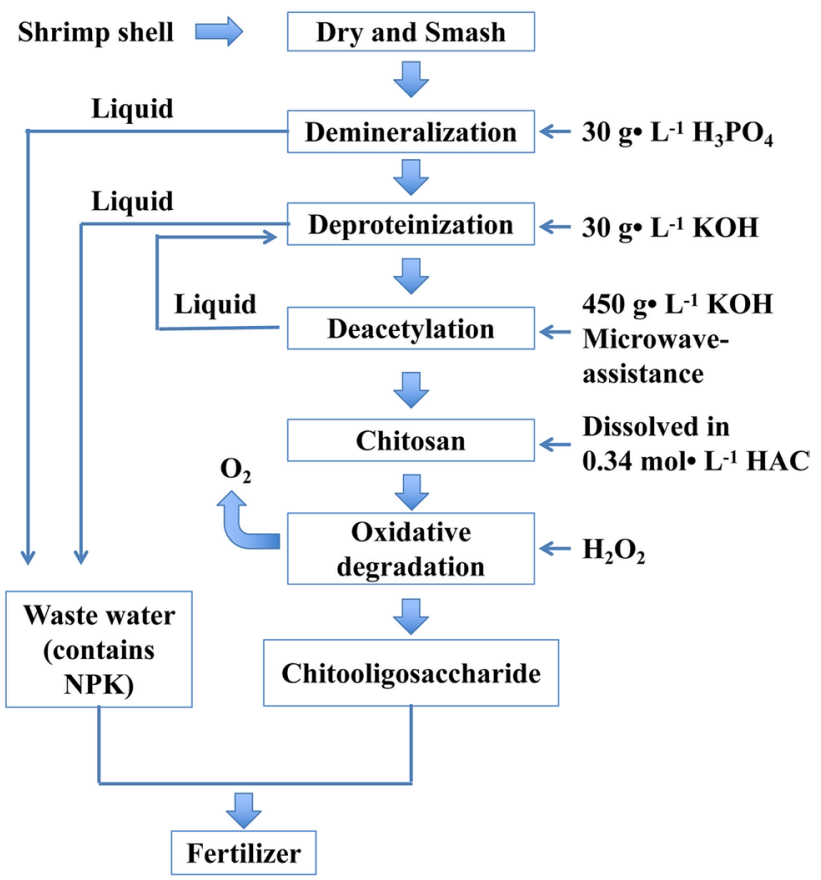

Fig. 2 Process flow diagram of COS fertilizer derived from shrimp shells

to plant requirements when used in an agricultural setting. Moreover, liquid waste and solid waste generated during the process was totally recycled, making COS valuable as fertilizer. The detailed process flow diagram of COS fertilizer from shrimp shells is presented in Fig. 2.

\section{Effects of COS with different DDA on the germination of wheat seeds}

Using chitosan oligomer (28 kDa, 78\% DDA) to coat zucchini seeds has been shown to shorten germination time and increase germination percentage (Cristóbal et al. 2012). COS (70\% DDA) has also been reported to be valuable as an elicitor enhancing the germination of barley seeds during seed priming (Lan et al. 2016). Additionally, Kananont and colleagues (2010) reported that chitosans with $70 \%$ and $80 \%$ DDA could significantly improve the germination of Dendrobium bigibbum var. compactum and that chitosan with $70 \%$ DDA could enhance the germination of Dendrobium formosum. This suggests that the DDA of chitosan may have a major impact on seed germination; however, limited data are available on the relationship between the DDA of COS and its effect on the germination of wheat seeds.

In this study, wheat seeds were soaked in COS with different DDA, and the germination percentage was recorded every day. Compared to the control group, a higher germination rate was observed with seeds soaked in COS (Fig. 3). During the first $24 \mathrm{~h}$, no significant differences in germination percentage were observed among all groups. After $48 \mathrm{~h}$, the highest germination percentage was observed with the treatment of $72.12 \%$ DDA, showing a significant difference compared to the control $(P<0.05)$.

\section{Analysis of enzyme activities and estimation of biochemical components}

Germination involves complex physiological and biochemical processes (Bewley 1997). During germination, intrinsic enzymes, such as amylase and protease, are activated after the uptake of water by dry seeds. The low-molecular weight metabolites produced by the hydrolysis of starch and protein participate in respiratory events and provide energy for the seedlings (Müntz et al. 1998; Mohan et al. 2010; Zhu et al. 2017). Changes in enzyme activity and stored biochemical components significantly affect seed vigor (Nandi et al. 1995). In this study, changes in enzyme activity and contents of sugar, starch, and protein were assessed from 0 to $24 \mathrm{~h}$ during germination (Fig. 4).

During germination, the activity of $\beta$-amylase increased in the first $6 \mathrm{~h}$, with its activity approximately 6-10 times higher than that of the $\alpha$-amylase in the tested samples (Fig. 4a, b). COS with DDA of $63.79 \%$ and $72.12 \%$ significantly increased the $\beta$-amylase activity $(P<0.05)$, with the highest $\beta$-amylase activity $\left(260.35 \mathrm{mg} \cdot \mathrm{min}^{-1} \cdot \mathrm{g}^{-1}\right)$ observed in the $72.12 \%$ DDA-treated group. After $12 \mathrm{~h}$, the $\beta$-amylase activity considerably decreased, which was analogous to an earlier report that the $\beta$-amylase activity significantly increased while the $\alpha$-amylase activity had negligible 
Fig. 3 Effects of COS with different degrees of deacetylation on the germination of wheat seeds. UN refers to the seeds treated with distilled water, used as the control. Data are expressed as means \pm SDs $(n=3)$. Different letters indicate statistically significant results $(P<0.05)$ based on one-way ANOVA with Tukey's test

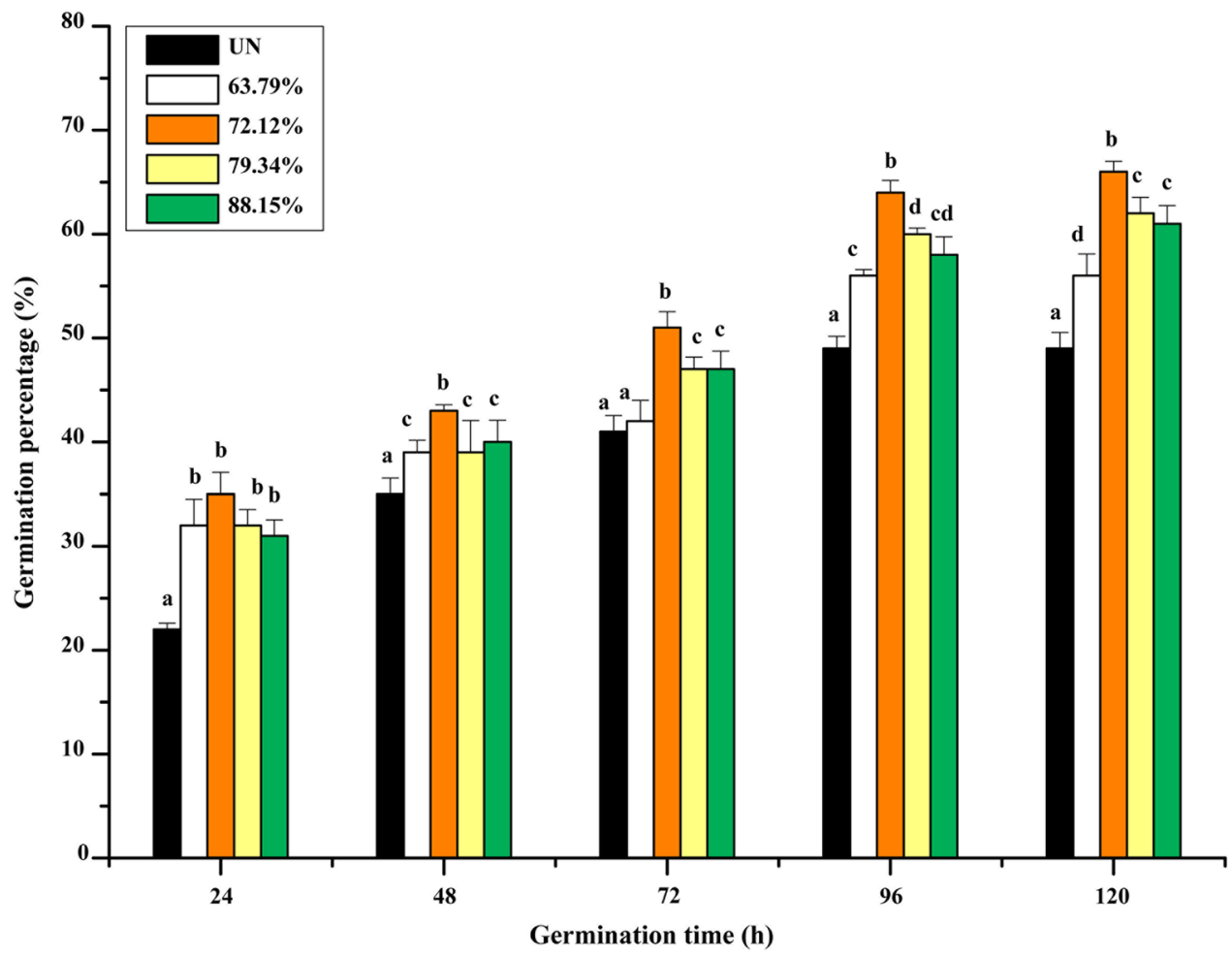

change when nitric oxide was used as an inducer during the early stages of germination (Zhang et al. 2005). $\beta$-Amylase activity is a key indicator of germination potential, while $\alpha$-amylase influences the speed of seedling growth in later stages of germination (Nandi et al. 1995). $\beta$-Amylase activity mainly depends on the release of free $\beta$-amylase, while bound $\beta$-amylase, which is linked to glutenin with a disulfide bond, has negligible activity (Sopanen and Laurièr 1989). Cysteine-endopeptidases have been reported to liberate the bound $\beta$-amylase from glutenin and increase its activity (Guerin et al. 1992). The increase in $\beta$-amylase activity in this study may be due to the release of $\beta$-amylase by endoprotease. Moreover, COS with different DDA were shown to enhance the protease activity compared to the control $(P<0.05)$, of which the COS with $72.12 \%$ DDA showed the best effect (Fig. 4c).

Soluble sugar, a substrate of the glycolytic pathway, participates in respiratory activity providing adequate energy to support metabolism during germination (Attucci et al. 1991). During the first $12 \mathrm{~h}$, the soluble sugar content decreased. The seeds treated by COS with $72.12 \%$ DDA showed the lowest sugar content (Fig. 4e). Metabolism of protein and starch occur during the germination to support seedling growth (Kuraś 1986; Zhao et al. 2018). In this study, sugar consumption was more than the production of sugar by starch hydrolysis during germination. However, there was no regular change in the protein and starch contents during the first $24 \mathrm{~h}$ of germination when the seeds were treated with COS (Fig. 4d, f). This might be due to the dynamic balance between the consumption and synthesis of nutrients during early germination.

\section{Conclusion}

In this study, an eco-friendly method was used to produce $\mathrm{COS}$ with different DDA using $\mathrm{H}_{3} \mathrm{PO}_{4}$ and $\mathrm{KOH}$ instead of $\mathrm{HCl}$ and $\mathrm{NaOH}$. The liquid waste and solid waste generated during demineralization, deproteinization, and deacetylation were totally recycled, demonstrating that the shrimp shell could be wholly transformed into fertilizer. The above process resulted in a product with the fractions of $\mathrm{N}: \mathrm{P}_{2} \mathrm{O}_{5}: \mathrm{K}_{2} \mathrm{O}$ :chitooligosac charide $=7.94: 24.44: 10.72: 18.27$. Moreover, it was revealed that the DDA of COS could influence the germination of wheat seeds by increasing the activity of $\beta$-amylase and protease enzymes and the consumption of sugar. The COS with $72.12 \%$ DDA was found to be most effective in promoting the germination of wheat seeds.

\section{Materials and methods}

\section{Materials}

Whiteleg shrimp (Penaeus vannamei) shells were obtained from local aquatic products processing factories. Wheat seeds (Triticum aestivum L.) were purchased from the agro-market in Qingdao. 

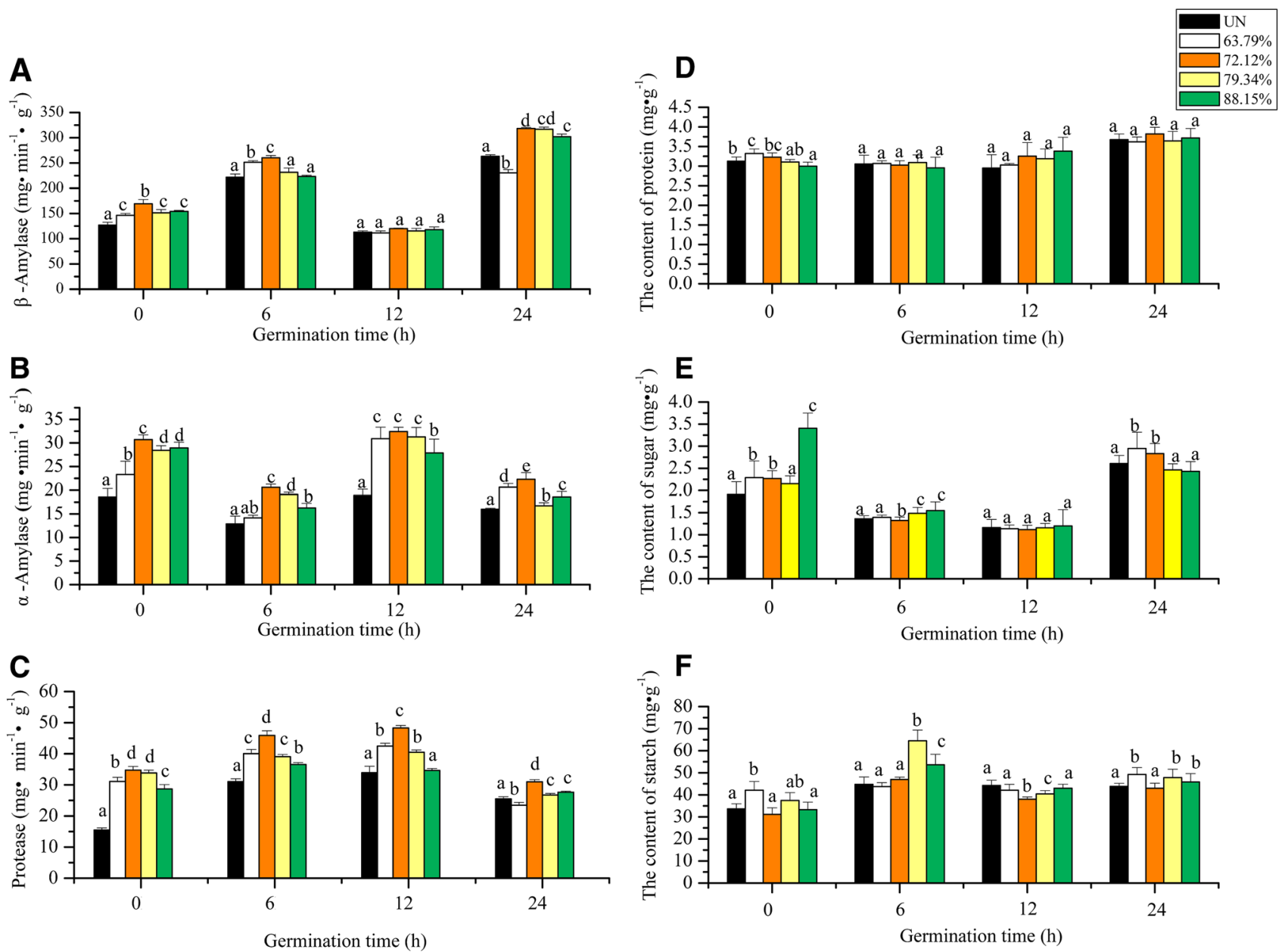

Fig. 4 Effect of COS with different degrees of deacetylation on the activity of enzymes and content of biochemical components during the early stages of germination. (a-c) The activities of $\beta$-amylase, $\alpha$-amylase, and protease, respectively; $(\mathbf{d}-\mathbf{f})$ the contents of protein,

\section{Demineralization of shrimp shells}

To evaluate the effect of phosphoric acid concentration on the demineralization of shrimp shells, $5 \mathrm{~g}$ shrimp shells were

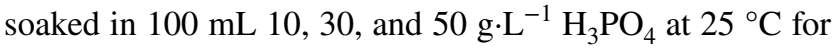
30 min with constant stirring for demineralization. The treated samples were then washed with distilled water until neutrality was reached then dried at $60^{\circ} \mathrm{C}$. The ash content was determined by putting the samples in a muffle furnace at $550{ }^{\circ} \mathrm{C}$. The degree of demineralization (DDM) was calculated using the following equation:

$\operatorname{DDM}(\%)=\frac{\left(A_{\mathrm{O}} \times \mathrm{O}\right)-\left(A_{\mathrm{P}} \times \mathrm{P}\right)}{A_{\mathrm{O}} \times \mathrm{O}} \times 100$,

where $A_{\mathrm{O}}$ was the ash content of the sample before demineralization, $A_{\mathrm{P}}$ was the ash content of the sample after demineralization, and $\mathrm{O}$ and $\mathrm{P}$ were the dry mass of the samples

starch, and sugar, respectively. UN refers to the seeds treated with distilled water, used as the control. Data are expressed as means \pm SDs $(n=3)$. Different letters indicate statistically significant results $(P<0.05)$ based on one-way ANOVA with Tukey's test

before and after demineralization, respectively. Furthermore, the variation of demineralization was investigated on different solid-to-solvent ratios of 1:4, 1:6, and 1:8.

\section{Deproteinization of shrimp shells}

The demineralized shrimp shells were soaked in 10,30, and $50 \mathrm{~g} \cdot \mathrm{L}^{-1} \mathrm{KOH}$ at different temperatures $\left(50{ }^{\circ} \mathrm{C}, 70{ }^{\circ} \mathrm{C}\right.$, and $90^{\circ} \mathrm{C}$ ) for $60 \mathrm{~min}$ with constant stirring for deproteinization. The sample was then centrifuged at $4800 \mathrm{rpm}$ for $15 \mathrm{~min}$ to remove the dissolved protein and chitin was obtained. The protein content of the sample was determined by the Kjeldahl method. The degree of deproteinization (DDP) was calculated using the following equation:

$\operatorname{DDP}(\%)=\frac{P_{\mathrm{S}}}{P_{\mathrm{R}}} \times 100$, 
where $P_{\mathrm{R}}$ was the protein content of demineralized sample, calculated by subtracting the chitin nitrogen from total nitrogen before deproteinization and $P_{\mathrm{S}}$ was the protein content of the supernatant (Holanda and Netto 2006; Synowiecki and Al-Khateeb 2000).

\section{Preparation of chitosans with different DDA}

The chitin extracts were mixed with $450 \mathrm{~g} \cdot \mathrm{L}^{-1} \mathrm{KOH}$ at $1: 15$ $(\mathrm{w} / \mathrm{v})$ in Teflon crucible and microwave heated at $600 \mathrm{~W}$ for $6,7,8$, and $8.5 \mathrm{~min}$, respectively. The treated samples were then washed with distilled water until neutrality was reached then dissolved in $0.34 \mathrm{~mol} \cdot \mathrm{L}^{-1}$ acetic acid. The supernatants were obtained after centrifugation at $4800 \mathrm{rpm}$ for $15 \mathrm{~min}$ and the $\mathrm{pH}$ was adjusted to $7.0 \mathrm{using} 40 \mathrm{~g} \cdot \mathrm{L}^{-1} \mathrm{KOH}$ to deposit chitosan. The chitosan was dried at $60^{\circ} \mathrm{C}$ and the DDA calculated using the following equation:

$\operatorname{DDA}(\%)=\frac{V \times c \times 10^{-3} \times 16}{m \times 0.0994} \times 100$,

where $V$ was the volume of $\mathrm{NaOH}$ consumed between the two abrupt changes of $\mathrm{pH}, \mathrm{c}$ was the concentration of $\mathrm{NaOH}$, and $\mathrm{m}$ was the dry weight of chitosan (Zhang et al. 2006).

\section{Preparation of chitooligosaccharides}

Two grams of chitosan with different DDA were individually dissolved in $100 \mathrm{~mL}$ of $0.34 \mathrm{~mol} \cdot \mathrm{L}^{-1} \mathrm{CH}_{3} \mathrm{COOH} . \mathrm{H}_{2} \mathrm{O}_{2}$ was added to a final concentration of $43 \mathrm{mmol} \cdot \mathrm{L}^{-1}$ and the oxidative degradation was carried out at $50{ }^{\circ} \mathrm{C}$ for $6 \mathrm{~h}$. The $\mathrm{pH}$ was adjusted to neutral with $\mathrm{KOH}$ to precipitate the large-molecular weight fractions then the supernatant was freeze-dried.

\section{Characterization of chitosan and COS}

\section{Viscosity measurement}

The chitosan sample was dissolved in $0.2 \mathrm{~mol} \cdot \mathrm{L}^{-1} \mathrm{NaCl}$ and $0.1 \mathrm{~mol} \cdot \mathrm{L}^{-1} \mathrm{CH}_{3} \mathrm{COOH}$ at $25 \pm 0.1{ }^{\circ} \mathrm{C}$ to obtain a homogeneous solution. The intrinsic viscosity was then measured using a Ubbelohde viscometer (internal diameter of $0.6 \mathrm{~mm}$ ) (Sannan et al. 1976).

\section{Fourier transform infrared spectroscopy analysis}

The Fourier transform infrared (FTIR) spectrum of chitin and chitosan was obtained using an FTIR spectrophotometer (Nicolet iS10, Thermo Fisher Scientific, Madison, USA). The sample was mixed with potassium bromide and pressed to a disk. The FTIR frequency range and resolution used were $400-4000 \mathrm{~cm}^{-1}$ and $4 \mathrm{~cm}^{-1}$, respectively.

\section{Molecular weight analysis of $\mathrm{COS}$}

The molecular weight of COS was measured by high-performance liquid chromatography (HPLC) (Agilent 1260, Agilent Technologies, Santa Clara, CA, USA) using a TSKgel G4000 $\mathrm{PW}_{\mathrm{XL}}$ column $(30 \mathrm{~cm} \times 7.8 \mathrm{~mm}$, Tosoh, Tokyo, Japan) and eluted with a solution of $0.2 \mathrm{~mol} \cdot \mathrm{L}^{-1} \mathrm{NaNO}_{3}$ and $0.01 \mathrm{~mol} \cdot \mathrm{L}^{-1} \mathrm{NaH}_{2} \mathrm{PO}_{4}(\mathrm{pH} 7.0)$.

\section{Wheat seed treatment and determination of germination percentage}

All the seeds were soaked in $75 \%$ ethanol for $10 \mathrm{~min}$ to remove the debris and mold, after which they were thoroughly washed with distilled water to remove ethanol. Sets of 100 seeds were then individually soaked in COS $\left(100 \mathrm{mg} \cdot \mathrm{L}^{-1}\right)$ with different DDA in centrifuge tubes and placed in an illumination incubator in the dark for $24 \mathrm{~h}$ at $25 \pm 0.1{ }^{\circ} \mathrm{C}$. Seeds soaked in distilled water were used as the control. After the soaking period, the seeds were transferred to individual Petri dishes containing a gauze and sheet of filter paper moistened with distilled water. All groups were placed in an illumination incubator for $12 \mathrm{~h}$ each of light and dark periods for 5 days at $25 \pm 0.1{ }^{\circ} \mathrm{C}$. The number of seedlings that emerged was recorded every day. Germination percentage was calculated as the total number of seedlings that emerged versus the total number of seeds sown.

\section{Assay of amylase and protease activities}

One gram of seed sample was mixed with $0.01 \mathrm{~mol} \cdot \mathrm{L}^{-1}$ phosphate buffer $(\mathrm{pH} 7.0)$ and grounded on ice then diluted to $50 \mathrm{~mL}$ using a phosphate buffer. The supernatant was obtained after centrifugation at $10,000 \mathrm{rpm}$ for $10 \mathrm{~min}$ at $4{ }^{\circ} \mathrm{C}$ and subsequently used for enzyme and protein assays. The amylase and protease activities were determined according to published methods (Hameed et al. 2013; Osman 2002).

\section{Assay of soluble sugar, starch and protein}

The supernatant of ground seed sample was obtained according to the method mentioned above, and the soluble protein content of the seed sample in the supernatant was determined using Folin-phenol reagent (Lowry et al. 1951). The content of soluble sugar and starch was obtained according to methods published by Maness (2010) and Bellasio et al. (2014) with slight modifications. Total soluble sugar of seed samples was extracted using $80 \%$ ethanol for $30 \mathrm{~min}$ at $70{ }^{\circ} \mathrm{C}$ after fully grinding on the ice. The supernatant was obtained after centrifugation at $4800 \mathrm{rpm}$ for $15 \mathrm{~min}$ and the sugar content was measured using phenol-sulfuric acid method (Kochert 1978). The centrifugation sediment was boiled for 
$15 \mathrm{~min}$ and soaked in $9.2 \mathrm{~mol} \cdot \mathrm{L}^{-1}$ perchloric acid on ice for $15 \mathrm{~min}$. After centrifugation at $4800 \mathrm{rpm}$ for $15 \mathrm{~min}$, the supernatant was collected and the sediment was soaked in $4.6 \mathrm{~mol} \cdot \mathrm{L}^{-1}$ perchloric acid on ice for another $15 \mathrm{~min}$. After centrifuging twice, the supernatant was merged and used to measure the starch content by phenol-sulfuric acid method (Kochert 1978).

\section{Statistical analysis}

All statistical analyses were performed using SPSS version 22.0 software (SPSS, Inc., Chicago, USA). All experiments were carried out in three replicates and results presented as mean \pm standard deviation (SD). Differences among more than two groups were analyzed by one-way analysis of variance (ANOVA) followed by Tukey's test. Differences with $P$ values of less than 0.05 were considered statistically significant.

Acknowledgements This work was supported by the Fundamental Research Funds for the Central Universities (201864002) and the Key Science and Technology Fund of Shandong Province (2015ZDZX05003).

Author contributions LZ and ML conducted the preparation of chitosan and chitooligosaccharides with different degrees of deacetylation from shrimp shell waste. XF and TZ conducted the test on the germination promotion of wheat seeds with chitooligosaccharides. XF and LZ analyzed and integrated all the data, finalized the figures, and wrote the original draft of the manuscript. LL helped with targeted metabolites data analysis. HM designed this program and supervised the entire project. All authors reviewed and edited the manuscript.

\section{Compliance with ethical standards}

Conflict of Interest All the authors declare that they have no conflict of interest.

Animal and human rights statement This article does not contain any studies with human participants or animals performed by any of the authors.

Open Access This article is distributed under the terms of the Creative Commons Attribution 4.0 International License (http://creativeco mmons.org/licenses/by/4.0/), which permits unrestricted use, distribution, and reproduction in any medium, provided you give appropriate credit to the original author(s) and the source, provide a link to the Creative Commons license, and indicate if changes were made.

\section{References}

Aam BB, Heggset EB, Norberg AL, Sørlie M, Vårum KM, Eijsink VG (2010) Production of chitooligosaccharides and their potential applications in medicine. Mar Drugs 8:1482-1517

Al Sagheer FA, Al-Sughayer MA, Muslim S, Elsabee MZ (2009) Extraction and characterization of chitin and chitosan from marine sources in Arabian Gulf. Carbohydr Polym 77:410-419
Attucci S, Carde J, Raymond P, Saint-Gès V (1991) Oxidative phosphorylation by mitochondria extracted from dry sunflower seeds. Plant Physiol 95:390-398

Bajaj M, Winter J, Gallert C (2011) Effect of deproteination and deacetylation conditions on viscosity of chitin and chitosan extracted from Crangon crangon shrimp waste. Biochem Eng J 56:51-62

Bellasio C, Fini A, Ferrini F (2014) Evaluation of a high throughput starch analysis optimised for wood. PLoS One 9:e86645

Benhabiles MS, Salah R, Lounici H, Drouiche N, Goosen MFA, Mameri N (2012) Antibacterial activity of chitin, chitosan and its oligomers prepared from shrimp shell waste. Food Hydrocoll 29:48-56

Bewley JD (1997) Seed germination and dormancy. Plant Cell 9:1055-1066

Cabrera J, Messiaen J, Cambier P, Cutsem P (2006) Size, acetylation and concentration of chitooligosaccharide elicitors determine the switch from defence involving PAL activation to cell death and water peroxide production in Arabidopsis cell suspensions. Physiol Plantarum 127:44-56

Cristóbal LV, Chirinos A, Tacoronte M, Mora A (2012) Chitosan oligomers as bio-stimulants to zucchini (Cucurbitapepo) seed germination. Agric (Pol'nohospodárstvo) 58:113-119

Guerin JR, Lance RCM, Wallace W (1992) Release and activation of barley beta-amylase by malt endopeptidases. J Cereal Sci 15:5-14

Hameed A, Sheikh MA, Farooq T, Basra SMA (2013) Chitosan priming enhances the seed germination, antioxidants, hydrolytic enzymes, soluble proteins and sugars in wheat seeds. Agrochimica $57: 32-46$

Hamel LP, Beaudoin N (2010) Chitooligosaccharide sensing and downstream signaling: contrasted outcomes in pathogenic and beneficial plant-microbe interactions. Planta 232:787-806

Holanda HD, Netto FM (2006) Recovery of components from shrimp (Xiphopenaeus kroyeri) processing waste by enzymatic hydrolysis. J Food Sci 71:298-303

John S, Pratya C, Gauri SM (2006) Chitin extraction from black tiger shrimp (Penaeus monodon) waste using organic acids. Sep Sci Technol 41:1135-1153

Kananont N, Pichyangkura R, Chanprame S, Chadchawan S, Limpanavech $P$ (2010) Chitosan specificity for the in vitro seed germination of two Dendrobium orchids (Asparagales: Orchidaceae). Sci Hortic 124:239-247

Kochert G (1978) Carbohydrate determination by phenolsulphuric acid method. In: Hellebust JA, Craigie JS (eds) Handbook of phycological methods: physiological and biochemical methods. Cambridge University Press, Cambridge, pp 95-97

Kumari S, Rath P, Sri Hari Kumar A, Tiwari TN (2015) Extraction and characterization of chitin and chitosan from fishery waste by chemical method. Environ Technol Innov 3:77-85

Kuraś M (1986) Activation of rape (Brassica napus L.) embryo during seed germination. IV. Germinating embryo. The first zones of mitoses, starch and DNA synthesis and their expansion pattern. Acta Soc Bot Poloniae 55:539-563

Lan W, Wang W, Yu Z, Qin Y, Luan J, Li X (2016) Enhanced germination of barley (Hordeum vulgare L.) using chitooligosaccharide as an elicitor in seed priming to improve malt quality. Biotechnol Lett 38:1935-1940

Lowry OH, Rosebrough NJ, Farr AL, Randall RJ (1951) Protein measurement with the Folin phenol reagent. J Biol Chem 193:265-275

Ma LJ, Li YY, Wang LL, Li XM, Liu T, Bu N (2014a) Germination and physiological response of wheat (Triticum aestivum) to presoaking with oligochitosan. Int J Agric Biol 16:766-770

Ma Z, Wang W, Wu YP, He Y, Wu T (2014b) Oxidative degradation of chitosan to the low molecular water-soluble chitosan over peroxotungstate as chemical scissors. PLoS One 9:e100743 
Maness N (2010) Extraction and analysis of soluble carbohydrates. In: Sunkar R (ed) Plant stress tolerance: methods and protocols, 2nd edn. Springer, New York, pp 341-370

Mohammed MH, Williams PA, Tverezovskaya O (2013) Extraction of chitin from prawn shells and conversion to low molecular mass chitosan. Food Hydrocoll 31:166-171

Mohan BH, Malleshi NG, Koseki T (2010) Physico-chemical characteristics and non-starch polysaccharide contents of Indica and Japonica brown rice and their malts. LWT Food Sci Technol 43:784-791

Müntz K, Becker C, Pancke J, Schlereth A, Fischer J, Horstmann C, Kirkin V, Neubohn B, Senyuk V, Shutov A (1998) Protein degradation and nitrogen supply during germination and seedling growth of vetch (Vicia sativa L.). J Plant Physiol 152:683-691

Nandi S, Das G, Sen-Mandi S (1995) $\beta$-Amylase activity as an index for germination potential in rice. Ann 75:463-467

Nyachiro JM, Clarke FR, DePauw RM, Knox RE, Armstrong KC (2002a) Temperature effects on seed germination and expression of seed dormancy in wheat. Euphytica 126:123-127

Nyachiro JM, Clarke FR, DePauw RM, Knox RE, Armstrong KC (2002b) The effects of cis-trans ABA on embryo germination and seed dormancy in wheat. Euphytica 126:129-133

Osman AM (2002) The advantages of using natural substrate-based methods in assessing the roles and synergistic and competitive interactions of barley malt starch-segrading enzymes. J Inst Brewing 108:204-214

Percot A, Viton C, Domard A (2003) Optimization of chitin extraction from shrimp shells. Biomacromol 4:12-18

Sannan T, Kurita K, Iwakura Y (1976) Studies on chitin, 2. Effect of deacetylation on solubility. Makromol Chem Phys 177:3589-3600

Singkhornart S, Edou-ondo S, Ryu GH (2014) Influence of germination and extrusion with $\mathrm{CO}_{2}$ injection on physicochemical properties of wheat extrudates. Food Chem 143:122-131

Sopanen T, Laurièr EC (1989) Release and activity of bound betaamylase in a germinating barley grain. Plant Physiol 89:244-249
Synowiecki J, Al-Khateeb NA (2000) The recovery of protein hydrolysate during enzymatic isolation of chitin from shrimp Crangon crangon processing discards. Food Chem 68:147-152

Tawaha ARA, Al-Tawaha M, Al-Ghzawi AL, Al-Ghzawi A (2013) Effect of chitosan coating on seed germination and salt tolerance of lentil (Lens culinaris L.). Res Crop 14:489-491

Vander P, Domard A, El Gueddari NE, Moerschbacher BM (1998) Comparison of the ability of partially $N$-acetylated chitosans and chitooligosaccharides to elicit resistance reactions in wheat leaves. Plant Physiol 118:1353-1359

Viarsagh MS, Janmaleki M, Pisheh HF, Masoumi SJ (2010) Chitosan preparation from persian gulf shrimp shells and investigating the effect of time on the degree of deacetylation. J Paramed Sci 1:2-7

Yen MT, Yang JH, Mau JL (2009) Physicochemical characterization of chitin and chitosan from crab shells. Carbohydr Polym 75:15-21

Younes I, Hajji S, Frachet V, Rinaudo M, Jellouli K, Nasri M (2014) Chitin extraction from shrimp shell using enzymatic treatment. Antitumor, antioxidant and antimicrobial activities of chitosan. Int J Biol Macromol 69:489-498

Younes I, Hajji S, Rinaudo M, Chaâbouni M, Jellouli K, Nasri M (2016) Optimization of proteins and minerals removal from shrimp shells to produce highly acetylated chitin. Int J Biol Macromol 84:246-253

Zhang H, Shen WB, Zhang W, Xu LL (2005) A rapid response of betaamylase to nitric oxide but not gibberellin in wheat seeds during the early stage of germination. Planta 220:708-716

Zhang Y, Xue C, Li Z, Zhang Y, Fu X (2006) Preparation of halfdeacetylated chitosan by forced penetration and its properties. Carbohydr Polym 65:229-234

Zhao M, Zhang H, Yan H, Qiu LL, Baskin CC (2018) Mobilization and role of starch, protein, and fat reserves during seed germination of six wild grassland species. Front Plant Sci 9:234

Zhu L, Adedeji AA, Alavi S (2017) Effect of germination and extrusion on physicochemical properties and nutritional qualities of extrudates and tortilla from wheat. J Food Sci 82:1867-1875 